\title{
Fire Risk Potential Checking in Forests using Fire Risk Model
}

\author{
Sayed Ali Hasheminasab ${ }^{1}$, Mojtaba Pirnazar ${ }^{2}$, Sayed Hafez Hasheminasab ${ }^{2}$, ArashZand \\ Karimi $^{2}$, Saeid Eslamian ${ }^{3}$, Kaveh Ostad-Ali-Askari ${ }^{4 *}$, Vijay P. Singh ${ }^{5}$, Nicolas R. Dalezios ${ }^{6}$, \\ Mohsen Ghane ${ }^{7}$, Ali Mirkhalafi ${ }^{4}$ \\ ${ }^{I}$ Department of Natural Resources, Yasooj University, Yasooj, Iran \\ ${ }^{2}$ Department of Remote Sensing, Tabriz University, Tabriz, Iran \\ ${ }^{3}$ Water Engineering Department, Isfahan University of Technology, Isfahan, Iran \\ ${ }^{4 *}$ Department of Civil Engineering, Isfahan (Khorasgan) Branch, Islamic Azad University, Isfahan, Iran \\ ${ }^{5}$ Department of Biological and Agricultural Engineering \&Zachry Department of Civil Engineering, Texas A \\ and M University, 321 Scoates Hall, 2117 TAMU, College Station, Texas 77843-2117, U.S.A. \\ ${ }^{6}$ Laboratory of Hydrology, Department of Civil Engineering, University of Thessaly, Volos, Greece \& \\ Department of Natural Resources Development and Agricultural Engineering, Agricultural University of \\ Athens, Athens, Greece. \\ ${ }^{7}$ Department of Civil Engineering, South Tehran Branch, Islamic Azad University, Tehran, Iran \\ *Corresponding Author: Dr. Kaveh Ostad-Ali-Askari, Department of Civil Engineering, Isfahan (Khorasgan) \\ Branch, Islamic Azad University, Isfahan, Iran.Emails: Koa.askari@khuisf.ac.ir, Kaveh.oaa2000@gmail.com

\begin{abstract}
Forests are one of the most valuable wealth on the earth planet and are living place for animals and plants, so protecting of them is an important and necessary order. One of the main reasons of forest annihilation is not controlled fires that destroy wide areas of forest and cause desertification. Remote sensing and GIS can be so much beneficial for studying Fire risk. In this research we investigated fire risk in protected forests in Central Alborz that has occurred every year and caused to plenty of damages. In this research Fire Risk method was used which included gradient environment factors, gradient direction and vegetation cover. Eventually area's fire risk maps were prepared which had weak relation with previous fire data and this point demonstrates low efficiency of presented model.
\end{abstract}

Keywords: Remote Sensing and GIS, Forest, Fire Risk Model, Fire Risk, Central Alborz's Forest.

\section{INTRODUCTION}

Forest are the most beautiful natural source of our environment and play important role in physical and mental health of organisms. Health of forest in every place is indicator of ecological conditions in that area (Zhang \& Chen; 2007). One of dangers that threatens forests is fire which causes to area ecology change by irreparable damages (Xu et al, 2005; Vakalis et al, 2004) and threatens these habitat makers permanently (Marozas et al., 2007) in the way that annual average of fire forests areas has been estimated six to fourteen million hectare in the world (Encinas et al., 2007). Actually forest's fire with either natural source or human source has harmful and destructive effects on human's life (Kazemi et al., 2005Podur et al., 2002). Increasing the number of times of fire occurrence in north of Iran's forests in recent years,confronts environment, forests, villages and their residents in wide range with damages and a lot of casualties. As a result of these fires not only forests of north has been damaged but also heavy financial damages has been imposed to country, whereas with necessary predictions and providing suitable technical solutions, ability to prevent of happening these incidents is easy and simple (Hoshyarkhah \& JamshidiAlashti, 2007).Therefore, preventive proceedings about fire incident are unavoidable in forests to prevent from their irreparable damages. One of the ways to control these fires is identifying fire critical points in forests area. Lack of enough knowledge about these points causes to start and spread fire in forest, delay to restrain it and will incur hurt to life of animals and plants in forest (Jaiswal et al., 2002). Some studies have been done about fire function in Iran's forests and most of these researches are novel. In the same way Mohammadi and colleagues launched to provide areas maps which have danger of forest fire based on some factors such as vegetation cover, physiography, continental and human (distance from raods and rivers) in a part of Pave river. In this research, map of fire areas was prepared by field operation and using of global 
positioning system. Then effective factors in fire incident and its spread were weighed by using Analytical Hierarchy process method (AHP) and action was taken to provide fire danger zoning map by using weighing layer and weighing coefficient that are related to each factor. Conclusions demonstrated that 90 percent of fire burned areas are in zones with high risk. (Mohammadi et al., 2010) used artificial neural network to predict fire risk of forests and pastures Izeh county. Conclusions demonstrated multilayerperceptron algorithm and hyperbolic function were efficient to create correlation between climatology data and fire incidence. Due to the importance of the issue of fire in forests and identification necessity of talented areas and sensitive to fire, different studies have been done as yet in this field in different parts of the world. Salvati and Ferrara (2015) have done validation of fire risk indicator MEDALUS, by using statistic methods based on multivariate analysis. This research has been done in Greece and set to occurrence fire rating in area and they calculated area of ignited surface in different users (Urban, grassland, forest, etcetera) by using different indicators. Arnett and colleagues in a research set to recognize vulnerability of forests by using remote sensing in different scales. In this research assessment of fire in forests of south of Canada has been done by using images of Rapid Eye and Lanset. In addition to mapping of fire danger, correlation between fire and type of cover has been obtained. It can be concluded that most of mentioned studies to evaluate of fire capability have emphasized about different environmental factors and assigning suitable weigh to them, by checking done researches. Also using of geographical information system tools capability could facilitate zoning and occurrence modeling and probability of fire danger (Chuvieco \& Congalton, 1989; Jaiswal et al., 2002; Ertenet al., 2004; Salamatiet al., 2011) so that importance of remote sensing and geographical information systems use has been made clear in information development and fire prediction (Akpinar\&Usul, 2003). Therefore, due to the importance of forests fire prevention by using of geographical information systems and due to the frequent of fire occurrence in forests of Central Alborz, this research intends to identify critical points of fire risk in forests of area by evaluating chosen models.

\section{ZONE OF STUDY}

Mazandaran province with about 23756.4 square kilometer extent, included nearly 1.46 of whole country's area that according to country divisions in year 1391 and public enumeration in year 1390, has 20 counties, 58 cities and 3073943 populations. Zone of study located in Noshahr city with 320 square kilometer area and has 58 degree and 29 minutes to 51 degrees and 40 minutes' east longitude and 36 degree and 15 minutes to 36 degrees and 37 minutes' north latitude. Location of study zone has been illustrated in figure(1). Central Alborz protected forests have plant species such as trees and have shrubs such as Alder, Oak, Zelkova, Honeylocust, Hornbeam, Jungle tomato, Warts,Fig, etcetera and have animal species such as Shchuka, Brown Bear, Tiger, Fox, Hog, Toad, Snake, etcetera (Tarzbanet al., 1392 page 26-29).

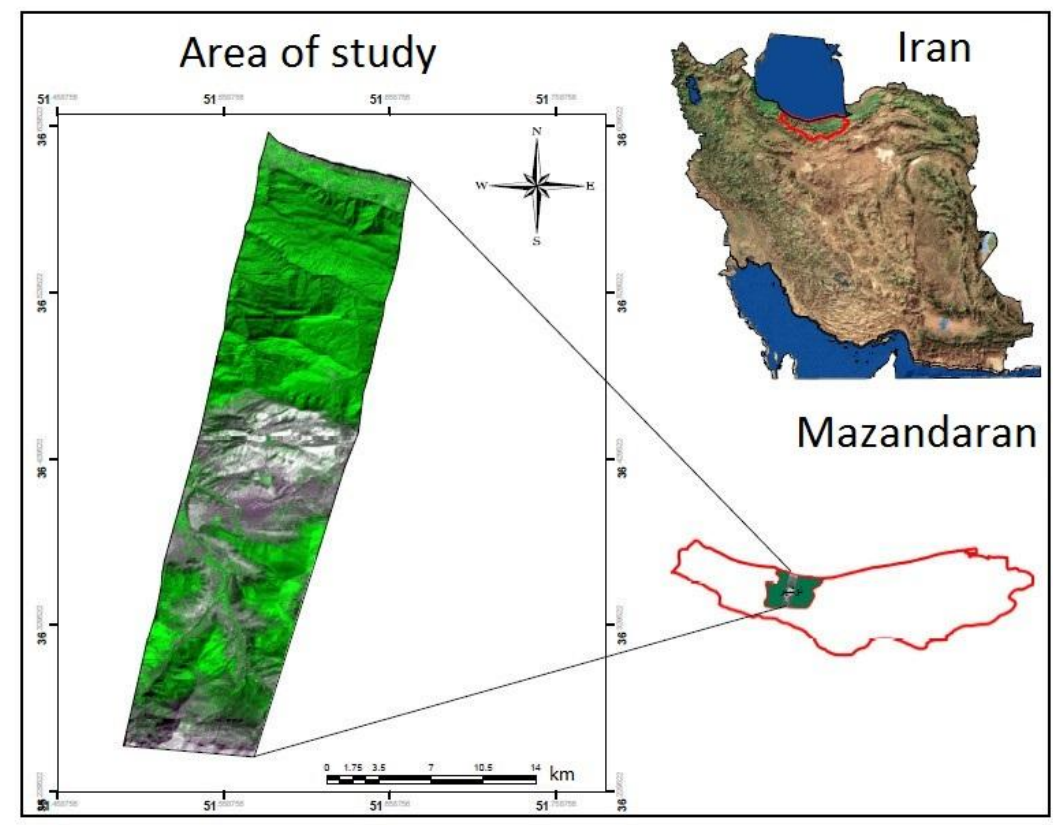

Figure1. Geographical location of area of study 


\section{MATERial AND MethoD}

\subsection{Using Data}

1- Satellite's images of TM sensor Landsat 5 with 165-35 pass and row and 2010 date.

2- Digital elevation model (DEM) in dimensions of 30 meter of ASTER sensor.

3- Area fire data during 15 recent years that were prepared by Nature source and Mazandaran province forests protecting organization.

Table1. Data of Fired Area

\begin{tabular}{|c|c|c|c|c|}
\hline Fired area (hectare) & Date of fire & Area & Area of forestry & Row \\
\hline 1 & 2000 & Chiler & Kheiroudkenar & 1 \\
\hline 0.035 & 2001 & Velerdeh & Marzanabad & 2 \\
\hline 0.2 & 2004 & Ahakchal & Soleimanabad & 3 \\
\hline 1 & 2005 & Katro & Kajour & 4 \\
\hline 0.15 & 2005 & Aroush & Noshahr & 5 \\
\hline 0.02 & 2005 & $\begin{array}{c}\text { Ghalaben- } \\
\text { Berken }\end{array}$ & Kajour & 6 \\
\hline 0.1 & 2008 & Mukala & Peimoud & 7 \\
\hline 0.08 & 2008 & Alichal & Kheiroudkenar & 8 \\
\hline 0.39 & 2008 & Zanous-Tange & Kajour & 9 \\
\hline 0.075 & 2010 & Si-Sangan & Salahe-din Kala & 10 \\
\hline
\end{tabular}

\subsection{Using model}

Using environmental factors to determine fire talented areas.

Fire occurrence is function of many conditions and factors that environmental factors affection is undeniable in their occurrence and spread. the most important and the most effective environmental factors that has a lot of affection in occurrence and spread of fire, are: gradient, direction of gradient, vegetation.

Affection of these factors can be defined as follows:

-Direction of dominated hot wind

-Comparative relation between surface gradient and hot wind direction.

-Vital vegetable mass rate (Biomass) that exists in gradients

Gradients that faced to dominated hot wind and has more biomass, are in more fire risk. Also sharper gradients increase risk of fire spread. Because fire flames can be transferred upward quickly in sharper gradients and this causes to rapid spread of fire to amplitudes upper parts (NajarAzali, 1392. Page 2022).

With considerate of any of these 3 factors, fire risk final formula as follows:

Fire Risk $=\frac{\left(\frac{\text { slope }}{90}\right)+\left(1-\frac{\text { abs }(180-\text { aspect })}{180}\right)+\left(\frac{N D V I+1}{2}\right)}{3}$

Fire risk layer has been prepared as amount between zero and one that zero indicates minimum risk and one indicates maximum risk.

In this method, after preparing area's digital elevation data via ENVI software, gradients layer and direction of gradient were extracted. Then on Lands at satellite's images that related to (35-164) zone, with the help of ENVI software, steps of preprocessing that included geometric and atmosphere correction were done and vegetation layer (NDVI), was extracted from image. In the following, gradient's layers, gradient's direction and vegetation were transferred by Arc GIS software. Used layers became standardization and are introduced as map according to any of (1-3) formula's part. 

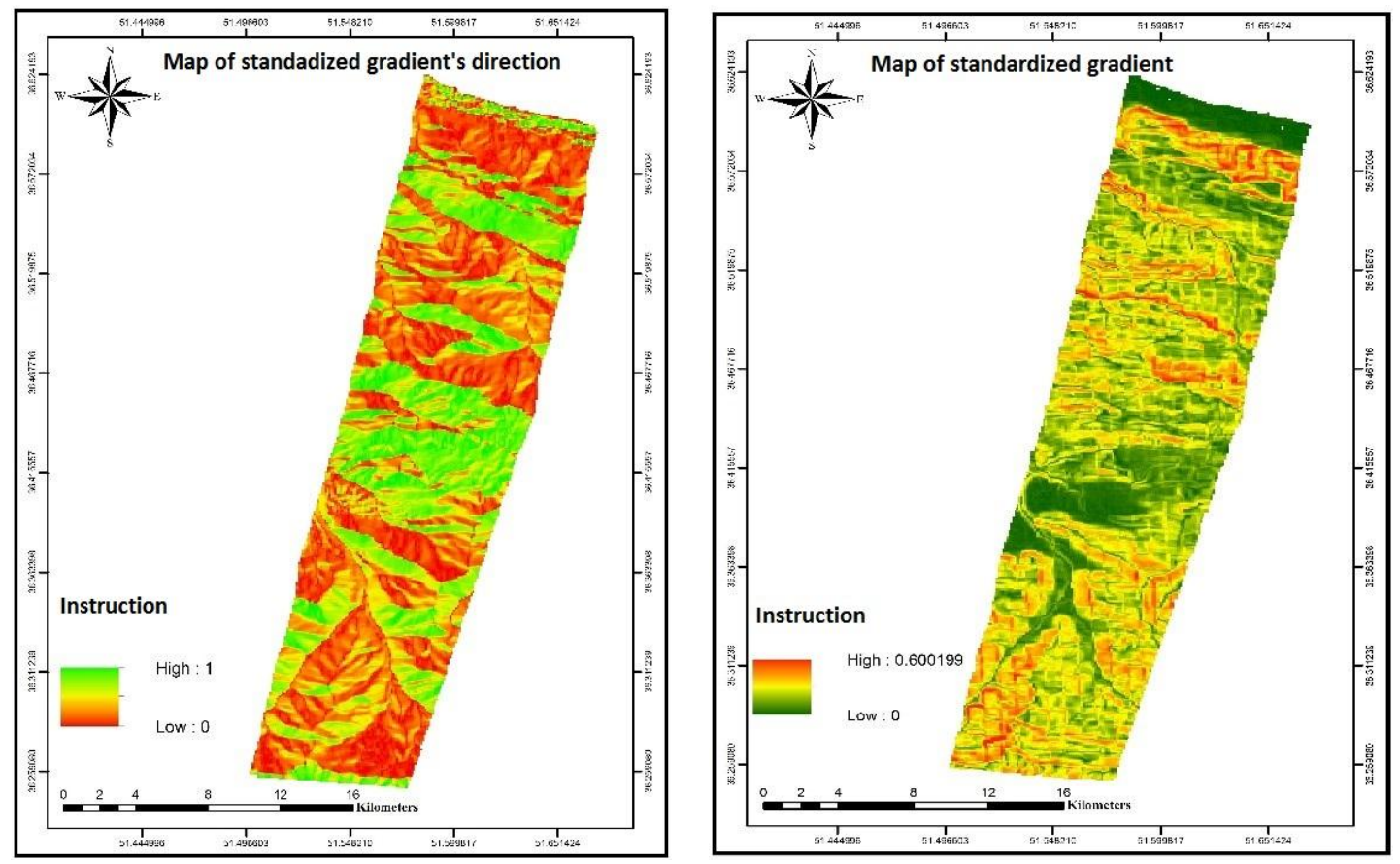

Figure2. Map of Standardized Gradient's direction. Figure3. Map of standardized gradient

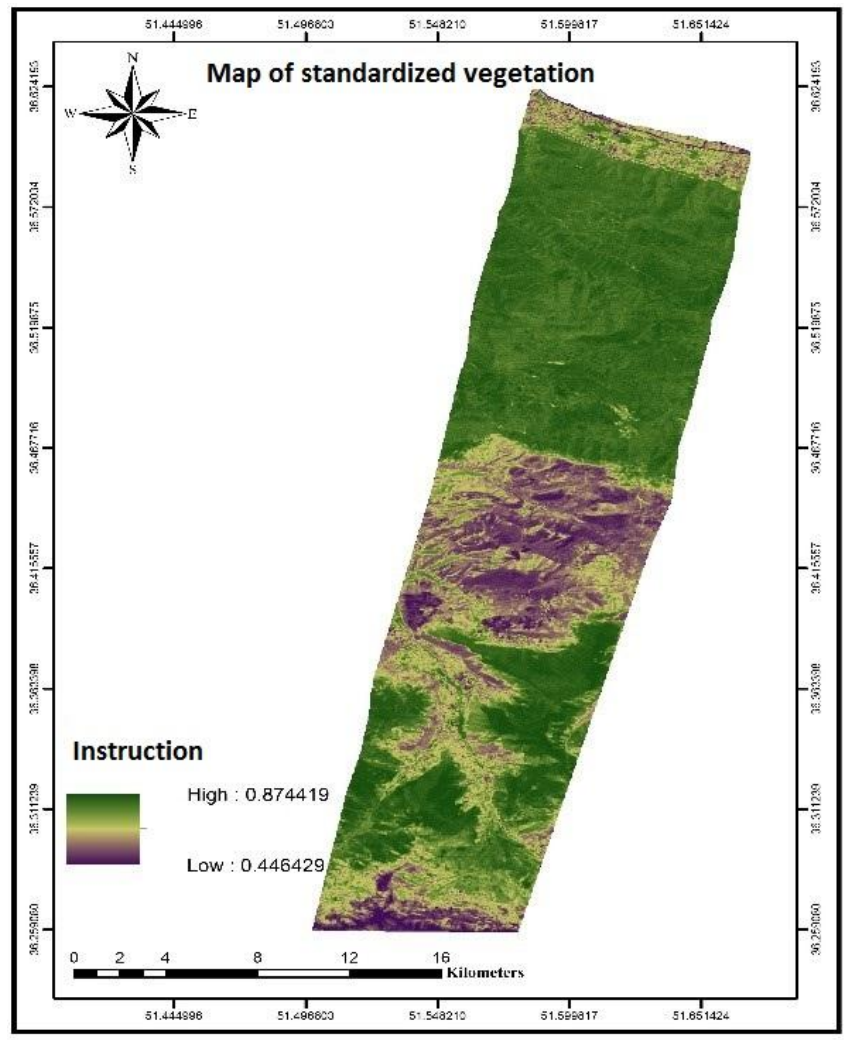

Figure4. Map of Standardized Vegetation

\section{CONCLUSION AND Discussion}

The most important process of each research is, obtained conclusions from research which in that answer of a lot of questions is revealed. In this process, investigate of hypothesis became possible and also necessary preparation is provided for suggestions presentation and improvement of current condition.

Here, fire risk's map was obtained by combination of related layers and through formula (1). As it is being illustrating, numerical value is between zero and one that zero indicates minimum risk and one indicates maximum risk. 


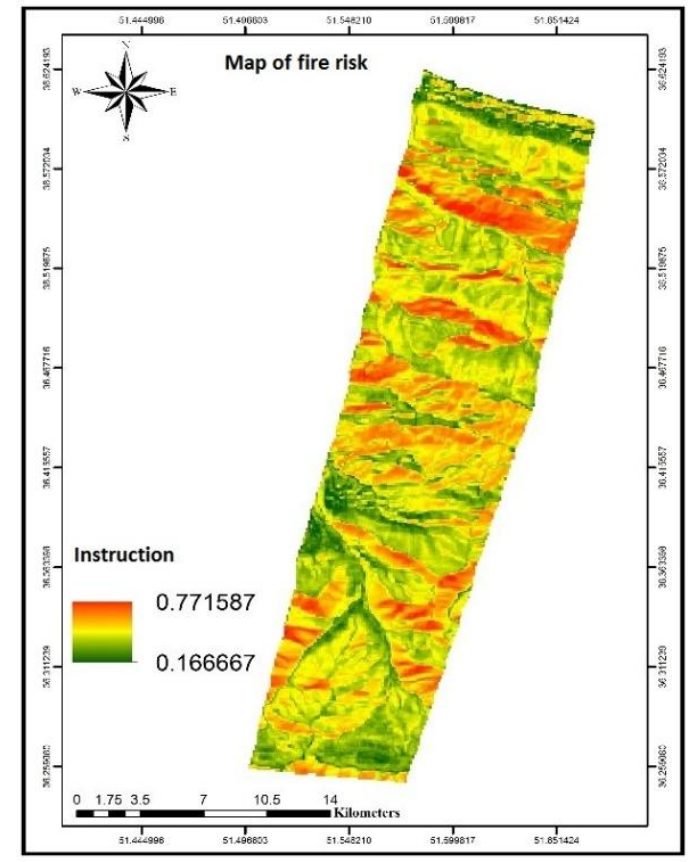

Figure5. Map of Fire Risk with Fire Risk Model

\subsection{Investigation of Rate of Fire Risk Method's Correctitude and Precision}

To check out the rate of fire risk method's correctitude and precision that is combination of environmental factors in estimation of fire risk's rate in area, information that is related to fire occurrence that happened before was used. Conclusions have been demonstrated in below map and table.

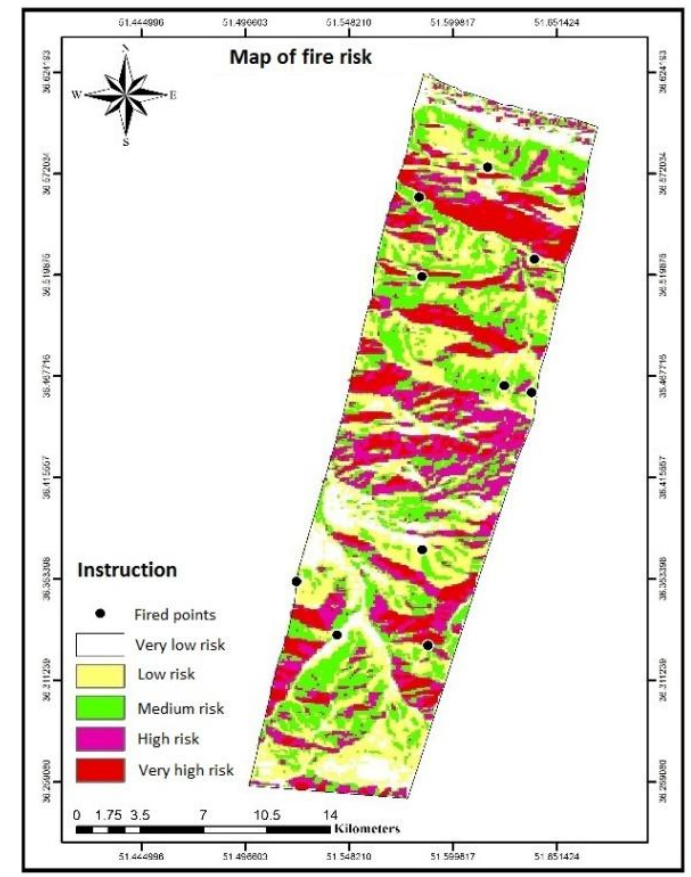

Figure6. Combination Map of Risk and Occurred Fire in Area

Table2. Number of Fire Occurrence in Different Degrees of Fire Risk in Fire Risk Model

\begin{tabular}{|c|c|}
\hline Number of fire occurrence & Degrees of fire risk \\
\hline 2 & Very low risk \\
\hline 5 & Low risk \\
\hline 3 & Medium risk \\
\hline 0 & High risk \\
\hline 0 & Very high risk \\
\hline
\end{tabular}


Also area of each risk's range, was calculated that has been demonstrated as below table and diagram.

Table3. Area of risk's different ranges in using model in square kilometer

\begin{tabular}{|c|c|c|c|c|c|}
\hline $\begin{array}{c}\text { VERY HIGH } \\
\text { RISK }\end{array}$ & HIGH RISK & MEDIUM RISK & $\begin{array}{c}\text { LOW } \\
\text { RISK }\end{array}$ & $\begin{array}{c}\text { VERY LOW } \\
\text { RISK }\end{array}$ & $\begin{array}{c}\text { DIFFERENT } \\
\text { LEVELS OF } \\
\text { RISK }\end{array}$ \\
\hline 43.21 & 59.94 & 86.29 & 90.75 & 38.57 & $\begin{array}{c}\text { AREA ( FIRE } \\
\text { RISK MODEL) }\end{array}$ \\
\hline
\end{tabular}

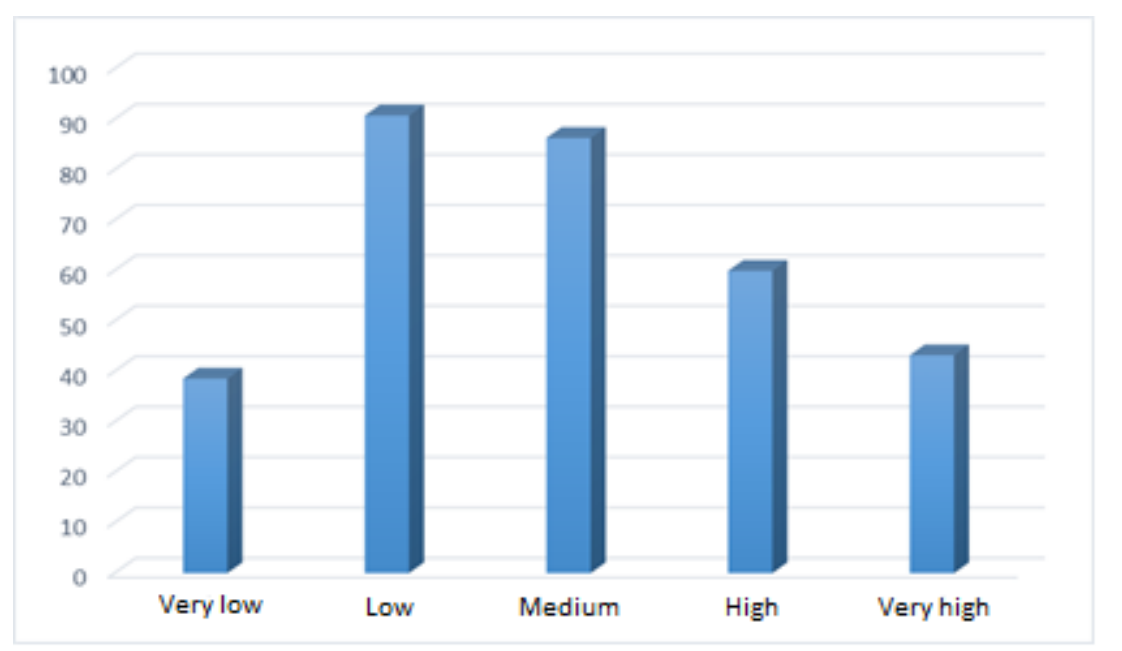

Figure7. Diagram of fire occurrence risk of different ranges area in Fire Risk model

\section{CONCLUSION AND SUGGESTIONS}

In this research, researcher tried to consider basic factors in fire occurrence and prepared fire risk map by using of Fire Risk model. In this model, environmental factors such as gradient, gradient direction and elevation is considered. Generally situating of most number of occurred fires point in the zone with low risk shows very low correlation between resulted map from this model and former occurred fires in zone. Obtained conclusion from this research can be used for further researches so that in fire map preparation, some models and scales are used that have more affection on zone's fire. Also according to heavy damages of fire in country, it is offered toorgans that related to protecting forest and pastures specially Nature Sources and Forestry Organization and also Environment Organization to prevent heavy damages imposition in forests and protect more practical from these valuable sources of our country with preparing up to date maps by experts in this field.

\section{REFERENCES}

[1] Trzban, Sadegh; AsgharHadian, Seyed Ali; Shohadaei, SeyedHamed; Janbazghobadi, GholamReza; Pezeshki, Mohammad; KazemiKaverdi, Mohammad Mehdi et al (1392). Mazandaran protest. Tehran: Iran textbook printing and publishing company.

[2] Ali mahmoudiSarab, Sajad; Feqhi, Jahangir; Jabbarianamiri, Bahman (1391). Prediction of fire occurrence in forests and pastures by using artificial neural network. Practical ecology, first year, second issue, autumn and winter of 1391.

[3] Najar azali, Nasim (1392).Forests fire risk assessment by using remote sensing and geographical information system in Arasbaran's forests. Thesis to get master degree in remote sensing and geographical information systemfield, Aras Pardis international, Tabriz university, faculty of geography.

[4] Akpinar, E. and Usual, N., 2003. GIS and forest fire.Project of INTA Space Turk, Engineering Department, Middle East Technical University, 11p.

[5] Arnett, J.T.T.R., Nicholas, C.C., Lori D., Robert W.F., 2015. Detecting forest damage after a low-severity fire using remote sensing at multiple scales. International Journal of Applied Earth Observation and Geoformation 35, pp: 239-246.

[6] Chuvieco, E., Congalton, R.G. 1989. Application of remote sensing and geographic information system to forest fire hazard mapping. Remote Sens. Environ. 29: 147-159.

[7] Encinas, A.H., Encinas, L.H., White, S.H., Del Rey,A.M. and Sanchez, G.R., 2007. Simulation offorest fire fronts using cellular automata. AdvancedEngineering Software, 38: 372-378. 
[8] Erten, E., Kurgun, V., veMusaoglu, N. (2004). Forest Fire Risk Zone Mapping from Satellite Imagery and GIS: A Case Study. XX.th, Congress of the International Society for Photogrammetry and Remote Sensing (ISPRS), July, Istanbul, Turkey, Proceedings, 12 - 25.

[9] Hoshyarkhah, B. and JamshidiAlashti, R., 2007. Fire regimes in forests and strategies of opposition with that. Proceeding of the Second Conference on Opposition with Natural Accidents, Tehran, Iran, 26 -28 Dec. 2007: 25-34.

[10] Jaiswal, R.K., Mukherjee, S., Raju, D.K., Saxena, R. 2002. Forest fire risk zone mapping from satellite imagery and GIS, International Journal of Applied Earth Observation and Geoformation, 4 (2002), Pp: 110 .

[11] Kazemi, S. M., 2005. Fire and forest ecosystems. Livestock, industry and culture journal: 79-81.

[12] Marozas, V., Racinskas, J. and Bartkevicius, E., 2007.Dynamics of ground vegetation after surface fires in hemiborealPinussylvestris forests. ForestEcology and Management, 250(1-2): 47-55.

[13] Mohammadi, F., Shabanian, N., Pourhashemi, M. and Fatehi, P., 2010. Risk zone mapping of forest fire using GIS and AHP in a part of Paveh forests. Iranian Journal of Forest and Poplar Research, 18(4): 569586.

[14] Podur, J., Martell, D.L. and Knight, K., 2002. Statistical quality control analysis of forest fire activity in Canada. Canadian Journal Forest Research, 32: 195-205.

[15] Salamati, H., Mostafalu, H., and Honardoust, F. 2011. Evaluation and forest fire risk mapping using GIS in the Golestan forests. Proceeding of first conference of fire on natural resources lands.

[16] Salvati, L., Ferrara, A. 2015. Validation of MEDALUS Fire Risk Index using Forest Fires Statistics through a multivariate approach. Ecological Indicators 48, pp: 365-369.

[17] Vakalis, D., Sarimveis, H., Kiranoudis, C., Alexandridis, A., and Bafas, G., 2004. A GIS based operational system for wild land fire crisis management I. mathematical modeling and simulation. Applied Mathematical Modeling, 28(4), 389-410.

[18] Xu, D., Dai, L.M., Shao, G.F., Tang, L., and Wang, H. 2005. Forest fire risk zone mapping from satellite images and GIS for Baihe forestry Bureau, Jilin China. Journal of forestry research, 15(3): 169-174.

[19] Zhang, Q.F., and Chen, W.J. 2007. Fire cycle of the Canada's boreal region and its potential response to global change. Journal of forestry research, 18(1): 55-59.

[20] Ostad-Ali-Askari, K., Shayannejad, M. 2015, Study of sensitivity of Autumnal wheat to under irrigation in Shahrekord, Shahrekord City, Iran. International Journal of Agriculture and Crop Sciences, 8 (4), $602-605$.

[21] Shayannejad, M., Akbari, N., Ostad-Ali-Askari, K. 2015, Study of modifications of the river physical specifications on muskingum coefficients, through employment of genetic algorithm. International Journal of Development Research, 5(3), 3782-3785.

[22] Ostad-Ali-Askari, K., Shayannejad, M. 2015, The Reviews of Einstein's Equation of Logarithmic Distribution Platform and the Process of Changes in the Speed Range of the Karkheh River, Khuzestan province, Iran. International Journal of Development Research, 5(3), 3786-3790.

[23] Ostad-Ali-Askari, K., Shayannejad, M., Ghorbanizadee-Kharazi, H. 2015, Assessment of artificial neural network performance and exponential regression in prediction of effective rainfall, International Journal of Development Research, 5(3),3791-3794.

[24] Shayannejad, M. Akbari, N. and Ostad-Ali-Askari, K. 2015, Determination of the nonlinear Muskingum model coefficients using genetic algorithm and numerical solution of the continuity. Int. J. of Science: Basic and Applied Research, 21(1),1-14.

[25] Ostad-Ali-Askari, K., Shayannejad, M. 2015, The Study of Mixture Design for Foam Bitumen and the Polymeric and Oil Materials Function in Loose Soils Consolidation. Journal of Civil Engineering Research, 5(2), 39-44. DOI: 10.5923/j.jce.20150502.04

[26] Sayedipour, M., Ostad-Ali-Askari, K., Shayannejad, M. 2015, Recovery of Run off of the Sewage Refinery, a Factor for Balancing the Isfahan-Borkhar Plain Water Table in Drought Crisis Situation in Isfahan Province-Iran. American Journal of Environmental Engineering, 5(2): 43-46. DOI: 10.5923/j.ajee.20150502.02

[27] Ostad-Ali-Askari, K., Shayannejad, M. 2015, Developing an Optimal Design Model of Furrow Irrigation Based on the Minimum Cost and Maximum Irrigation Efficiency. International Bulletin of Water Resources \& Development, 3(2), 18-23.

[28] Ostad-Ali-Askari, K., Shayannejad, M. 2015, Presenting a Mathematical Model for Estimating the Deep Percolation Due to Irrigation. International Journal of Hydraulic Engineering, 4(1), 17-21. DOI: 10.5923/ j.ijhe.20150401.03.

[29] Ostad-Ali-Askari, K., Shayannejad, M. 2015, Usage of rockfill dams in the HEC-RAS software for the purpose of controlling floods. American Journal of Fluid Dynamics, 5(1), 23-29. DOI: 10.5923/ j.ajfd. 20150501.03. 
[30] Ostad-Ali- Askari, K., Shayannejad, M. 2015, The effect of heterogeneity due to inappropriate tillage on water advance and recession in furrow irrigation. Journal of Agricultural Science, 7(6), 127-136.

[31] Shayannejad, M., Ostad-Ali-Askari, K. 2015, Effects of magnetized municipal effluent on some chemical properties of soil in furrow irrigation. International Journal of Agriculture and Crop Sciences, 8(3), 482489.

[32] Ostad-Ali-Askari, K., Shayannejad, M. 2015, Optimal design of pressurized irrigation laterals installed on sloping land. International Journal of Agriculture and Crop Sciences, ISSN 2227-670X. 8(5), 792-797.

[33] Ostad-Ali-Askari K, Shayannejad M, Eslamian S, Navab-Pour B. 2016, Comparison of solution of SaintVenant equations by characteristics and finite difference methods for unsteady flow analyzing in open channel. International Journal of Hydrology Science and Technology, 6(3), 9-18.

[34] Ostad-Ali-Askari K, Shayannejad M, Eslamian S, et al. 2017, Deficit Irrigation: Optimization Models. Management of Drought and Water Scarcity. Handbook of Drought and Water Scarcity, Taylor \& Francis Publisher, USA. Vol. 3. $1^{\text {th }}$ Edition, pp: 373-389.

[35] Eskandari S, Hoodaji M, Tahmourespour A, Abdollahi A, Mohammadian-Baghi T, Eslamian S, Ostad-AliAskari K. 2017, Bioremediation of Polycyclic Aromatic Hydrocarbons by Bacillus Licheniformis ATHE9 and Bacillus Mojavensis ATHE13 as Newly Strains Isolated from Oil-Contaminated Soil. Journal of Geography, Environment and Earth Science International, 11(2): 1-11.

[36] Shayannejad M, Ostad-Ali-Askari K, Eslamian S, et al. 2017, Development of a new method for determination of infiltration coefficients in furrow irrigation with natural non-uniformity of slope. Sustain. Water Resour. Manag., 3(2): 163-169.

[37] Shojaei N, Shafaei-Bejestan M, Eslamian S, Marani-Barzani M, P. Singh V, Kazemi M, Ostad-Ali-Askari K. 2017, Assessment of Drainage Slope on the Manning Coarseness Coefficient in Mountain Area. International Journal of Constructive Research in Civil Engineering (IJCRCE), 3(1): 33-40.

[38] Bahmanpour H, Awhadi S, Enjili J, Eslamian S, Ostad-Ali-Askari K. 2017, Optimizing Absorbent Bentonite and Evaluation of Contaminants Removal from Petrochemical Industries Wastewater. International Journal of Constructive Research in Civil Engineering (IJCRCE), 3(2): 34-42.

[39] Shayannejad M, Eslamian S, Gandomkar A, Marani-Barzani M, Amoushahi-Khouzani M, Majidifar Z, Rajaei-Rizi F, Kazemi M, P. Singh V, Dehghan SH, Shirvani-Dastgerdi H.R, Norouzi H, Ostad-Ali-Askari K. 2017, A Proper Way to Install Trapezoidal Flumes for Measurements in Furrow Irrigation Systems. International Journal of Research Studies in Agricultural Sciences (IJRSAS), 3(7): 1-5.

[40] Dehghan Sh, Kamaneh S.A.A., Eslamian S, Gandomkar A, Marani-Barzani M, Amoushahi-Khouzani M, Singh V.P., Ostad-Ali-Askari K. 2017, Changes in Temperature and Precipitation with the Analysis of Geomorphic Basin Chaos in Shiraz, Iran. International Journal of Constructive Research in Civil Engineering (IJCRCE), 3(2): 50-57.

[41] Ostad-Ali-Askari K, Shayannejad M. 2016, FLOOD ROUTING IN RIVERS BY MUSKINGUM'S METHOD WITH NEW ADJUSTED COEFFICIENTS. International Water Technology Journal, IWTJ, 6(3): 189-194.

[42] Ostad-Ali-Askari K, Shayannejad M, Ghorbanizadeh-Kharazi H. 2017, Artificial Neural Network for Modeling Nitrate Pollution of Groundwater in Marginal Area of Zayandeh-rood River, Isfahan, Iran. KSCE Journal of Civil Engineering, 21(1):134-140. Korean Society of Civil Engineers. DOI 10.1007/s12205-016-0572-8.

[43] Shayannejad M, Ostad-Ali-Askari K, Ramesh A, Singh V.P., Eslamian S. 2017, Wastewater and Magnetized Wastewater Effects on Soil Erosion in Furrow Irrigation. International Journal of Research Studies in Agricultural Sciences (IJRSAS), 3(8): 1-14. http://dx.doi.org/10.20431/2454-6224.0308001.

[44] Shayannejad M, Soltani-Toudeshki A.R, Arab M.A, Eslamian S, Amoushahi-Khouzani M, MaraniBarzani M, Ostad-Ali-Askari K. 2017, A Simple Method for Land Grading Computations and its Comparison with Genetic Algorithm (GA) Method. International Journal of Research Studies in Agricultural Sciences (IJRSAS), 3(8): 26-38.

[45] Mohieyimen P, Eslamian S, Ostad-Ali-Askari K, Soltani M. 2017,Climate Variability: Integration of Renewable Energy into Present and Future Energy Systems in Designing Residential Buildings. International journal of Rural Development, Environment and Health Research(IJREH), 1(2): 18-30.

[46] Shayannejad M, Ostad-Ali-Askari K, Eslamian S, et al. 2017, Flow Hydraulic Investigation of the Wastewater on the Soil and Magnetic Field Effects in This Field. International Journal of Constructive Research in Civil Engineering (IJCRCE), 3(3): 1-15.

[47] Shayannejad M, Eslamian S, Singh V.P., Ostad-Ali-Askari K, et al. 2017, Evaluation of Groundwater Quality for Industrial Using GIS in Mountainous Region of Isfahan Province, Koh-Payeh, Isfahan, Iran. International Journal of Constructive Research in Civil Engineering (IJCRCE), 3(3): 24-37. 
[48] Eslamian S, P. Singh V, Ostad-Ali-Askari K, R. Dalezios N, Yihdego Y, et al. 2017, Assessment of Aridity Using Geographical Information System in Zayandeh-Roud Basin, Isfahan, Iran. International Journal of Mining Science (IJMS), 3(2): 49-61.

[49] Askari Z, Samadi-Boroujeni H, Fattahi-Nafchi R, Yousefi N, Eslamian S, Ostad-Ali-Askari K, P. Singh V, R. Dalezios N. 2017, Prediction Comparison of Flow Resistance in Channels with Rounded and Angular Coarse Rough Beds. American Research Journal of Civil and Structural, 3(1): 1-15.

[50] Ghane M, Alvankar S.R., Eslamian S, Amoushahi-Khouzani M, Gandomkar A, Zamani E, Marani-Barzani M, Kazemi M, Soltani M, Dehghan SH, P. Singh V, Ostad-Ali-Askari K, HaeriHamedani M, ShirvaniDastgerdi H.R., Zalaki-Badil N. 2017, Sensitivity Analysis of Runoff Model by SWAT to Meteorological Parameters: A Case Study of Kasillian Watershed, Mazandaran, Iran. International Journal of Research Studies in Agricultural Sciences (IJRSAS), 3(10): 1-20.

[51] Shayannejad M, Abedi M.S., Eslamian S, Ostad-Ali Askari K, Gandomkar A, Cheng A, et al. 2017, The Contribution of Artificial Charging in Optimal Exploitation of Water Resources, Isfahan, Iran. InternationalJournal of Mining Science (IJMS), 3(3): 9-20.

[52] Eslamian S, Ostad-Ali Askari K, et al. 2017, Guidelines to Optimal Design of Furrow Irrigation Based on Plants, Soil and Furrow Specifications. International Journal of Constructive Research in Civil Engineering (IJCRCE), 3(4): 20-39.

Citation: Dr. Kaveh Ostad-Ali-Askari et.al. (2017) Fire Risk Potential Checking in Forests using Fire Risk Model, International Journal of Constructive Research in Civil Engineering, 3(4), pp.67-75. DOI: http://dx.doi. org/10.20431/2454-8693.0304006

Copyright: () 2017 Dr. Kaveh Ostad-Ali-Askari, This is an open-access article distributed under the terms of the Creative Commons Attribution License, which permits unrestricted use, distribution, and reproduction in any medium, provided the original author and source are credited. 